\title{
Effect of different substrates on composting of poultry litter
}

\section{Ana Carolina Amorim Orrico ${ }^{1}$, Stanley Ribeiro Centurion ${ }^{2}$, Romildo Marques de Farias ${ }^{3}$, Marco Antonio Previdelli Orrico Junior ${ }^{4}$, Rodrigo Garófallo Garcia ${ }^{1}$}

\author{
${ }^{1}$ Curso de Zootecnia da Faculdade de Ciências Agrárias - UFGD/Dourados-MS, Brasil. \\ 2 Graduando do curso de Zootecnia - UFGD/Dourados-MS, Brasil. \\ ${ }^{3}$ Aluno Especial do Programa de Pós-Graduação em Zootecnia da FCA - UFGD. \\ ${ }^{4}$ Doutorando do Programa de Pós-Graduação em Zootecnia - UNESP/Jaboticabal-SP, Brasil. Fellowship granted by CNPq.
}

ABSTRACT - The objective was to evaluate the differences between distinct types of litter material and their combinations in the dynamics of degradation on the organic matter fractions and the quality of the final compound. The treatments were established according to material used as substrate for broiler litter: treatment 1 - rice husks; 2 - sugar cane bagasse; 3 - wood shavings; 4 - wood shavings + sugar cane bagasse; 5 - rice husks + sugar cane bagasse; and 6 - Napier grass. The following variables were monitored: temperature, levels of total solids (TS), volatile solids (VS), mass and volume of the pile, fibrous fraction, and levels and reductions of N, P and K during the process. Piles formed with Napier grass and sugar cane bagasse presented the highest average temperatures during composting. The greater average reductions in TS and VS were attained in piles with sugar cane bagasse (68.12 and 73.07\%, for TS and VS, respectively). The reductions of greatest volume occurred in piles with sugar cane bagasse $(52.08 \%)$, followed by Napier grass (50.56\%). Poultry litters composed of rice husks and wood shavings presented 13.21 and $10.23 \%$ of lignin, respectively, which contributed to the lower degradation of fibrous fraction and degradability. Substrates with lower lignin content were those with greatest organic matter degradation rate and had reduced losses of $\mathrm{N}$ levels during the process. Composting performance is affected by the initial substrate used to compose the poultry litter.

Key Words: broiler production, cellulose, lignin, temperature, total solids

\section{Introduction}

According to Brazilian Poultry Union (Ubabef), the Brazilian poultry production reached over 13 million tons in 2011, about $6.9 \%$ more than the total produced in the previous year. This growth leads to increase in the concern about waste production from the poultry industry, mainly poultry litter. The litter is responsible for a number of functions, such as protecting the bird from direct contact with the floor; it is used as a substrate for absorption of moisture, storage of feces, urine, and feathers and, in addition, it contributes to reducing the temperature fluctuations (Araujo et al., 2007). However, the large amount of manure that is accumulated in the litter turns it into an important source of contamination (Sampaio et al., 1999).

Until some years ago, the poultry litter was used in the feeding of ruminants, once it was a very common practice and was even encouraged all over the country until 2001, when it was banned by the Normative Instruction Number 15 from the Brazilian Ministry of Agriculture, Livestock and Food Supply, as a method to prevent potential risk of bovine spongiform encephalopathy (Dutra et al., 2005). After this statement, the litter could only be used in the fertilization of crop areas, which determined that the poultry production units should drive a new application for the waste generated by this animal production (Dutra et al., 2005).

The composting process is the most suitable method for waste recycling, which besides having the advantage of reducing mass, volume and pathogenic micro-organisms, also enables the obtainment of a final product with good fertilizing characteristics that should be consciously exploited for agricultural production (Orrico et al., 2007). Like any other biological process, composting needs some factors to ensure satisfactory results, including the most important ones: temperature, moisture, $\mathrm{pH}$ and chemical composition of the material; the latter is the most challenging to be controlled and thus leads to varied results during the process (Orrico Junior et al., 2010). Huang et al. (2008) and Perez et al. (2002) showed that the composition of the fibrous fraction of plant materials (cellulose, hemicellulose and lignin) significantly influences the degradation rate of these compounds, mainly when the lignin comprises the major part of the substrate. Thus, it is clear that the poultry litter content may vary significantly according to the initial litter material and the lignin content present in it (Orrico Junior et al., 2011). 
The objective of this study was to evaluate the differences between distinct types of litter material and their combinations in the dynamics of degradation on the organic matter fractions and the quality of the final compound.

\section{Material and Methods}

The research was conducted in the facilities of the Poultry Research Unit, where the samples from different types of poultry litter were collected during the period from January to May 2009. Broilers were housed in pens covered with different types of litter material such as rice husks, sugar cane bagasse, wood shavings, wood shavings + sugar cane bagasse, rice husks + sugar cane bagasse and Napier grass. The compost test was performed with the residue that was initially placed as litter substrate added to the spilled feed, feathers and manure generated by birds during a growing cycle.

At the beginning of the experiment, approximately $200 \mathrm{~kg}$ of poultry litter was used to build the composting piles. The windrowing was formed under field conditions in order to obtain more realistic results when compared with poultry house conditions. Then, the amount of incorporated material was increased in order to split it into three other treatments which provided better heat conservation into the piles and thus better composting results were attained.

The piles were built at the composting area with masonry floor with $2 \%$ slope for drainage of water excess. Six types of litter material with three replicates per treatment were used for the experiment. The treatments are described as follows: treatment 1 - rice husks; 2 - sugar cane bagasse; 3 - wood shavings; 4 - wood shavings + sugar cane bagasse; 5 - rice husks + sugar cane bagasse; and 6 - Napier grass, comprising the formation of 18 piles on the total.

During the composting assay, variables such as mass of piles, content of total solids (TS), volatile solids (VS) and volume occupied by piles were monitored on a weekly basis, except for temperature, which was assessed every morning at $08 \mathrm{~h} 00 \mathrm{~min}$ with a digital skewer thermometer that was inserted up to 3 different points (base, top and center) in each pile, and then, daily temperature was estimated based on the average value of the three readings. The volume of the piles was measured at the weighing and the composting material was kept in buckets of 100 liters (with intermediate gradations of 10 liters). At the weighing and volume estimates, samples were taken for determination of TS and VS levels.

The contents of cellulose, hemicellulose, lignin, nitrogen, phosphorus and potassium were assessed at the beginning and end of the process; samples were taken from piles in each process stage. The content of each component and the dry matter of the piles were considered for estimating the initial and their final quantities. The amount of N, P and K was determined by Digesdahl Hach digester, which promoted digestion of the total organic matter using sulfuric acid $\left(\mathrm{H}_{2} \mathrm{SO}_{4}\right)$ and hydrogen peroxide $\left(\mathrm{H}_{2} \mathrm{O}_{2}\right)$ at $50 \%$. Nitrogen was determined as described by Silva \& Queiroz (2006).

The phosphorus content was determined through colorimetric analysis, which is based on the forming of yellow compound from vanadomolybdophosphoric system at acidity of 0.2 to $1.6 \mathrm{~N}$ and then, the color developed was measured in a spectrophotometer model DR-2000 HACH. The phosphorus concentration was determined through a standard curve, which had a straight line plotted from previous standard concentrations between 0 and $52 \mathrm{mg} \mathrm{P} / \mathrm{mL}$. These standard concentrations were prepared according to methodology described by Malavolta et al. (1989). The concentration of potassium (K) was determined through atomic absorption spectrophotometer, model GBC 932 AA.

The contents of TS, VS and phosphorus were determined according to methodology described by Apha (2005). The cellulose and hemicellulose concentrations were estimated by determining the NDF and ADF, as described by Silva \& Queiroz (2006). The lignin was determined by potassium permanganate procedure, as described by Silva \& Queiroz (2006).

In order to analyze the test results from composting of poultry litter obtained with different substrates, a completely randomized design was adopted, with six treatments and three replications (piles), using the Tukey test for comparison of means $(\alpha=0.05)$. Statistical procedures were performed through GLM of SAS (Statistical Analysis System, version 6.0).

\section{Results and Discussion}

Temperature is an important parameter to evaluate the quality of the composting process. According to the results observed in studies (Table 1) of composting, when the temperature remains high for several days, it means that the material is undergoing intense degradation, which is good, because the quicker the litter material reaches stability, the greater the reduction of pathogenic microorganisms that do not tolerate high temperatures for so long.

Concerning this behavior, Curci et al. (2007), Torres et al. (2007) and Orrico et al. (2007) proved the efficiency of the composting process on the elimination of several species of pathogenic microorganisms, including sporulated bacteria such as Clostridium sp, highlighting the importance of maintaining the temperature at thermophilic ranges. 
Among the treatments, the piles of poultry litter with Napier grass had the highest temperature $(\mathrm{P}<0.05)$ during the composting process, while the piles mixed with rice husks and sugar cane bagasse presented the highest average temperature during the thermophilic phase. These results demonstrate that the presence of forage (Napier grass or sugar cane bagasse) in the composition of poultry litter allowed the increase and maintenance of temperatures during composting, which is probably explained by the greater content of nonstructural carbohydrates in the composition of forages, thus increasing the degradation by microorganisms and as a consequence, the heating of the piles.

In both comparisons of temperature, the worst performance was demonstrated by piles with rice husks as poultry litter material, because it probably represents a source of energy with reduced availability which prevented the rising of temperatures. In order to present a significant reduction of pathogenic microorganisms during the composting process, the substrate of the pile has to reach high temperatures that must be kept for several days (Orrico Junior et al, 2009). Low temperature for a short period of time may not be sufficient to sterilize the final compound. So, its use as a fertilizer can lead to contamination of the feed to be produced and therefore will contribute to the spread out of diseases on the farm property (Gonçalves \& Marin, 2007).

Table 1 - Average temperature $\left({ }^{\circ} \mathrm{C}\right)$ of the total period of composting and thermophilic stage of piles of poultry litter with different substrates

\begin{tabular}{lcc}
\hline Initial poultry litter material & Period & Thermophilic \\
\hline Rice husks & $39.93 \mathrm{c}$ & $52.55 \mathrm{~d}$ \\
Sugar cane bagasse & $42.81 \mathrm{ab}$ & $56.71 \mathrm{~b}$ \\
Wood shavings & $42.27 \mathrm{~b}$ & $54.53 \mathrm{c}$ \\
Wood shavings + sugar cane bagasse & $42.95 \mathrm{ab}$ & $56.85 \mathrm{ab}$ \\
Rice husks + sugar cane bagasse & $43.33 \mathrm{ab}$ & $57.76 \mathrm{a}$ \\
Napier grass & $43.58 \mathrm{a}$ & $57.00 \mathrm{ab}$ \\
P value & 0.035 & 0.023 \\
CV, \% & 13.45 & 12.45 \\
\hline
\end{tabular}

$\mathrm{P}$ - significance; $\mathrm{CV}$ - coefficient of variation.
The greatest reductions in TS, VS and volume $(\mathrm{P}<0.05)$ were achieved by the piles formed by poultry litter with sugar cane bagasse, followed by Napier grass and all treatments that had sugar cane bagasse as litter material (Table 2). This result is extremely important in production systems, since the reduction of pile mass contributes to better use of the space for composting, once it reduces the amount of the final product (compound), which facilitates storage and decreases the expenses for application.

The greater mass reductions during composting are probably related to the degradation of substrates, as previously discussed about the temperature. It is worth noting that the presence of forage (sugar cane and Napier) in the composition of poultry litter improved the degradation of waste during the process. So, composting of piles formed from litter with rice husks or wood shavings without sugar cane had the lowest reduction of TS mass, demonstrating their resistance to degradation. This increased resistance to degradation is coupled to the greater proportion of lignin (Table 3) contained in the material that initiated the composting process.

The evolution of various fractions of organic matter along the composting was studied by Francou et al. (2008), who concluded that among the constituents of the fiber, lignin is the main responsible for slowing down the decomposition of organic matter, once the rate of biodegradation of an organic material depends on the amount of lignin present in it.

Therefore, these authors indicated the lignin/(cellulose + hemicellulose) ratio as precise to predict the degradation potential of a material or to check whether the organic compound reached a satisfactory degradation for use as organic fertilizer. According to these authors, the greater the lignin/(cellulose + hemicellulose) ratio, the lower the biodegradation of the material, which ends up limiting its use in the composting process, if it is a residue, or indicating that the composting process reached the maturity stage, if it is a compound.

Table 2 - Reduction of total solids (TS), volatile solids (VS) and volume during the composting of poultry litter with different substrates

\begin{tabular}{lccc}
\hline Initial poultry litter material & & Reduction $(\mathrm{kg} / \mathrm{kg})$ \\
\cline { 2 - 4 } & $\mathrm{TS}$ & $\mathrm{vS}$ & Volume \\
\hline Rice husks & $0.523 \mathrm{~d}$ & $0.582 \mathrm{c}$ & $0.321 \mathrm{f}$ \\
Sugar cane bagasse & $0.681 \mathrm{a}$ & $0.731 \mathrm{a}$ & $0.521 \mathrm{a}$ \\
Wood shavings & $0.488 \mathrm{e}$ & $0.534 \mathrm{~d}$ & $0.344 \mathrm{e}$ \\
Wood shavings + sugar cane bagasse & $0.550 \mathrm{c}$ & $0.599 \mathrm{c}$ & $0.427 \mathrm{c}$ \\
Rice husks + sugar cane bagasse & $0.589 \mathrm{~b}$ & $0.647 \mathrm{~b}$ & $0.417 \mathrm{~d}$ \\
Napier grass & $0.559 \mathrm{bc}$ & $0.611 \mathrm{c}$ & $0.506 \mathrm{~b}$ \\
P value & 0.034 & 0.039 & 0.033 \\
CV, \% & 14.56 & 12.34 & 13.48 \\
\hline
\end{tabular}

$\mathrm{P}$ - significance; CV - coefficient of variation. 
The increase in lignin content (Table 3) occurred due to the quick reduction of other constituents of organic matter while this fraction got accumulated in the material. However, when considering the lignin in quantitative terms, i.e., the amount at the beginning of the composting process and the amount at the end of composting, reductions ranging from 0.563 to $0.312 \mathrm{~kg} / \mathrm{kg}$ (Table 4) were observed. In addition, the poultry litter produced with rice husks and wood shavings presented 132.1 and $102.3 \mathrm{~g}$ lignin/kg of TS, respectively, which contributed for these materials to present a reduction in the degradation of the fibrous fraction (Table 4) and consequently reduce its degradability.

The composting of poultry litter with sugar cane bagasse was the one with the greatest reductions in cellulose and hemicellulose, 0.774 and $0.742 \mathrm{~kg} / \mathrm{kg}$, respectively, unlike the litter with rice husks and wood shavings, which presented the lowest reductions of hemicellulose and cellulose, respectively. This finding is in agreement with studies conducted by Perez et al. (2002), who observed that lignin is a compound with limited degradation that also inhibits the breaking down of cellulose and hemicellulose of the plant material, acting as a physical barrier and protecting the fibers from attack by cellulolytic and hemicellulolytic microorganisms. Thus, it is believed that part of cellulose and hemicellulose that could be degraded will not be hydrolyzed during composting due to the resistant protection of lignin.

Phosphorus and potassium contents (Table 5) showed no differences $(\mathrm{P}>0.05)$ with respect to the different treatments at the beginning and end of the composting process. Thus, the substrate had no influence on the final composition of the compound. However, nitrogen levels were the most influenced by the type of litter substrate.

According to Orrico Junior et al. (2010), significant losses of nitrogen occur during the composting of poultry litter due to the unequal balance of the $\mathrm{C}: \mathrm{N}$ ratio of the material. Most of the nitrogen is lost by ammonia volatilization, which starts with the hydrolysis of nitrogen compounds by microorganisms that degrade the organic$\mathrm{N}$, leading to formation of $\mathrm{NH}_{+4} \cdot-\mathrm{N}$ (ammonification). The compound formed, $\mathrm{NH}_{+4}-\mathrm{N}$, is used in microbial growth or in the nitrification process. However, when its amount is greater than that assimilated by microorganisms, the compound is lost to the atmosphere as nitrogen oxides and ammonia; the latter represents the largest fraction of the losses. In the specific case of this study, it was observed that the treatments that had the lowest rates of degradation (rice husk, wood shavings and mixings with them) were the ones with the highest losses of nitrogen due to a lower microbial activity that is responsible for preventing the loss of nitrogen to the atmosphere.

Table 3 - Composition (g TS/kg) of fibrous fraction in each of the evaluated treatments

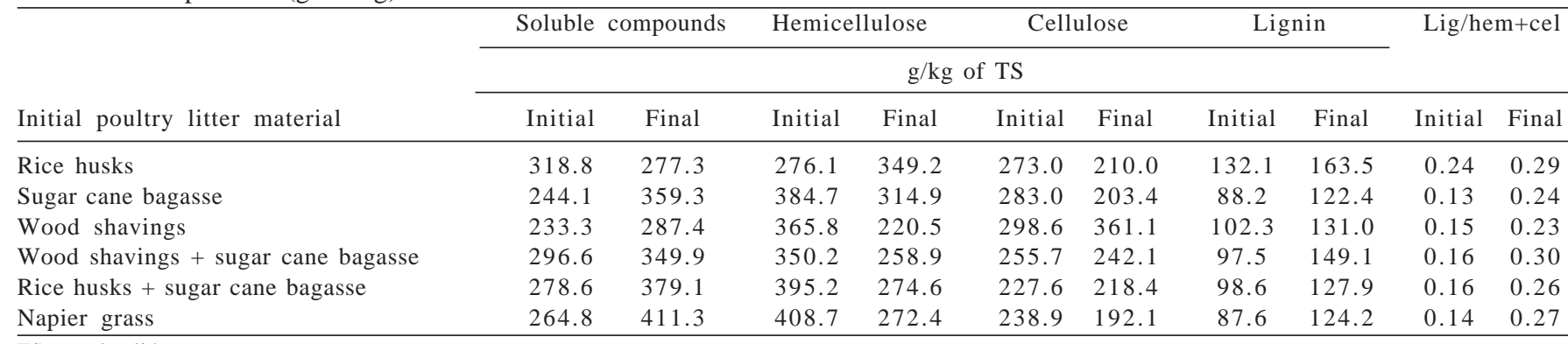

TS - total solids.

Table 4 - Reduction (kg/kg) of hemicellulose, cellulose and lignin during the composting process

\begin{tabular}{lccc}
\hline Initial poultry litter material & & $\mathrm{kg} / \mathrm{kg}$ \\
\cline { 2 - 4 } & Hemicellulose & Cellulose & $0.592 \mathrm{c}$ \\
Rice husks & $0.341 \mathrm{c}$ & $0.773 \mathrm{a}$ & $0.355 \mathrm{c}$ \\
Sugar cane bagasse & $0.742 \mathrm{a}$ & $0.380 \mathrm{~d}$ & $0.563 \mathrm{a}$ \\
Wood shavings & $0.691 \mathrm{ab}$ & $0.574 \mathrm{c}$ & $0.344 \mathrm{c}$ \\
Wood shavings + sugar cane bagasse & $0.667 \mathrm{~b}$ & $0.631 \mathrm{bc}$ & $0.312 \mathrm{c}$ \\
Rice husks + sugar cane bagasse & $0.732 \mathrm{a}$ & $0.654 \mathrm{~b}$ & $0.501 \mathrm{~b}$ \\
Napier grass & $0.713 \mathrm{a}$ & 0.018 & $0.390 \mathrm{c}$ \\
P value & 0.021 & 8.49 & 0.032 \\
CV, \% & 5.85 & 24.82 \\
\hline P-
\end{tabular}

$\mathrm{P}$ - significance; $\mathrm{CV}$ - coefficient of variation. 
Table 5 - Levels (g/kg TS) of nitrogen (N), phosphorus (P) and potassium (K) at the beginning and end of the composting process

\begin{tabular}{|c|c|c|c|c|c|c|c|c|c|}
\hline \multirow[t]{2}{*}{ Initial poultry litter substrate } & \multicolumn{2}{|c|}{ g N/kg TS } & \multirow{2}{*}{$\begin{array}{l}\text { Increment } \\
(\mathrm{g} / \mathrm{g})\end{array}$} & \multicolumn{2}{|c|}{ g P/kg TS } & \multirow{2}{*}{$\begin{array}{l}\text { Increment } \\
(\mathrm{g} / \mathrm{g})\end{array}$} & \multicolumn{2}{|c|}{ g K/kg TS } & \multirow{2}{*}{$\begin{array}{l}\text { Increment } \\
(\mathrm{g} / \mathrm{g})\end{array}$} \\
\hline & Initial & Final & & Initial & Final & & Initial & Final & \\
\hline Rice husks & $36.2 \mathrm{e}$ & $26.7 \mathrm{e}$ & $-0.267 \mathrm{e}$ & 11.7 & 23.9 & 2.036 & 3.3 & 7.7 & 1.358 \\
\hline Wood shavings & $34.5 d$ & $29.2 d$ & $-0.156 \mathrm{~d}$ & 11.0 & 15.6 & 1.412 & 3.1 & 6.8 & 1.175 \\
\hline Wood shavings + sugar cane bagasse & $36.5 c$ & $33.2 \mathrm{c}$ & $-0.913 c$ & 11.4 & 21.4 & 1.878 & 3.1 & 7.9 & 1.553 \\
\hline Rice husks + sugar cane bagasse & $33.2 \mathrm{c}$ & $32.0 \mathrm{c}$ & $-0.352 c$ & 11.4 & 23.4 & 2.062 & 3.1 & 8.2 & 1.631 \\
\hline $\mathrm{CV}, \%$ & 14.55 & 12.34 & 12.54 & 19.56 & 17.89 & 17.89 & 21.56 & 22.45 & 23.56 \\
\hline
\end{tabular}

TS - total solids.

\section{Conclusions}

The performance of the composting process of poultry litter is affected by the material used as substrate for the production of the litter. The substrates that have lower levels of lignin have the highest rates of degradation of several fractions of organic matter and keep the levels of nitrogen during the process.

\section{References}

AMERICAN PUBLIC HEALTH ASSOCIATION - APHA. Standard methods for examination of water and wastewater. 21.ed. Washington: American Water Works Association, 2005. 1368p.

ARAÚJO, J.S.; OLIVEIRA, V.; BRAGA, G.C. Desempenho de frangos de corte criados em diferentes tipos de cama e taxa de lotação. Ciência Animal Brasileira, v.8, p.59-64, 2007.

CURCI, V.C.L.M.; DUTRA, I.S.; DOBEREINER, J. et al. Précompostagem de cadáveres de bovinos acometidos pelo botulismo. Pesquisa Veterinária Brasileira, v.27, p.157-161, 2007.

DUTRA, I.S.; DÖBEREINER, J.; SOUZA, A.M. Botulismo em bovinos de corte e leite alimentados com cama de frango. Pesquisa Veterinária Brasileira, v.25, p.115-119, 2005.

FRANCOU, C.; LINÈRES, M.; DERENNE, S. et al. Infuence of green waste, biowaste and paper-cardboard initial ratios on organic matter transformations during composting. Bioresource Technology, v.99, p.8926-8934, 2008.

GONÇALVES, V.P.; MARIN, J.M. Fate of non O157 Shiga toxigenic Escherichia coli in composted cattle manure. Arquivos Brasileiros de Medicina Veterinária e Zootecnia, v.59, p.825-831, 2007.

HUANG, D.; ZENG, G.M.; FENG, C.L. et al. Degradation of leadcontaminated lignocellulosic waste by Phanerochaete chrysosporium and the reduction of lead toxicity. Environmental Science and Technology, v.42, p.4946-4951, 2008.

MALAVOLTA, E.; BOARETO, A.E.; PAULINO, V.T. Micronutrientes, uma visão geral. In: FERREIRA, M.E.; CRUZ, M.C. Micronutrientes na agricultura. Piracicaba: POTAFOS/ CNPq, 1989. p.1-33.

ORRICO JUNIOR, M.A.P.; ORRICO, A.C.A.; LUCAS JUNIOR, J. Compostagem da fração sólida da água residuária de suinocultura. Engenharia Agrícola, v.29, p.483-491, 2009.

ORRICO JUNIOR, M.A.P.; ORRICO, A.C.A.; LUCAS JUNIOR, J. Compostagem dos resíduos da produção avícola: cama de frangos e carcaças de aves. Engenharia Agrícola, v.30, p.538-545, 2010.

ORRICO JUNIOR, M.A.P.; ORRICO, A.C.A.; LUCAS JUNIOR, J. Produção animal e o meio ambiente: uma comparação entre potencial de emissão de metano dos dejetos e a quantidade de alimento produzido. Engenharia Agrícola, v.31, p.399-410, 2011.

ORRICO, A.C.A.; LUCAS JUNIOR, J.; ORRICO JUNIOR, M.A.P. Alterações físicas e microbiológicas durante a compostagem dos dejetos de cabras. Engenharia Agrícola, v.27, p.764-772, 2007.

PEREZ, J.; MUNOZ-DORADO, J.; DE LA RUBIA, T. et al. Biodegradation and biological treatments of cellulose, hemicellulose and lignin: An overview. International Microbiology, v.5, p.53-63, 2002.

SAMPAIO, M.A.P.M.; SCHOCKEN-ITURRINO, R.P.; SAMPAIO, A.A.M. et al. Estudo da população microbiana e da liberação de amônia da cama de frangos tratada com gesso agrícola. Arquivo Brasileiros de Medicina Veterinária e Zootecnia, v51, p.559-564, 1999.

SILVA, D.J.; QUEIROZ, A.C. Análise de alimentos: métodos químicos e biológicos. 3.ed. Viçosa, MG: Editora Universitária, 2006. 166p.

TORRES, P.; PÉREZ, A.; ESCOBAR, J. et al. Compostaje de biosolidos de plantas de tratamiento de aguas residuales. Engenharia Agrícola, v.27, p.267-275, 2007.

UNIÃO BRASILEIRA DE AVICULTURA - UBABEF. Relatório anual. Available at: $<$ http://www.abef.com.br/ubabef/exibenoticia ubabef.php?notcodigo=3113>. Accessed on: Jan. 3, 2012. 